\title{
THE LEAGUE OF NATIONS AND THE EMERGENCE OF INTERNATIONAL ADMINISTRATION: FINDING THE ORIGINS OF INTERNATIONAL INSTITUTIONAL LAW
}

\author{
Richard COLLINS*
}

\begin{abstract}
SUMMARY: 1. INTRODUCTION.-2. THE LEAGUE OF NATIONS AND THE EMERGENCE OF INTERNATIONAL ADMINISTRATION.-3. COMING TO TERMS WITH THE LEAGUE QUA INTERNATIONAL ORGANISATION.
\end{abstract}

\section{INTRODUCTION}

In contemporary reflections on the history of international law and international organization the creation of the League of Nations in the aftermath of the First World War stands as a critical dividing line between an older, pre-institutionalised era of sovereign coexistence and a modern era of cooperation, conflict resolution and institutional governance. Projecting forwards from this point, however, the legacy of the League in its somewhat short-lived existence is rather more mixed. In terms of what was clearly its primary purpose, to pacify inter-state diplomacy and put an end to the scourge of war, its overriding failure is well-known and does not need repeating here. However, in terms of the League's contribution to the project of international organisation its contribution has been considerable and often overlooked. In fact, as Pitman Potter has claimed, the League has arguably made «a far greater contribution to the progress of international organisation than any other institution in history» ${ }^{1}$. Indeed, as Philippe Sands and Pierre Klein have equally commented, that it failed in its primary purpose — and, indeed, did so quite

* Lecturer in International Law, University College Dublin. This text is based on remarks delivered at the conference: "The Legacy of the League of Nations», held in the University of Leicester, on $31^{\text {st }}$ January 2019. My thanks to Rossana Deplano for the invitation to give those remarks and to the participants for helpful comments and feedback.

1 PotTer, P. B., An Introduction to the Study of International Organization, $5^{\text {th }}$ edn, New York/London, Appleton-Century-Crofts, 1948, p. 257. Nevertheless, he immediately follows up these remarks by noting that «in a certain sense and in a certain specific situation [the League was also] history's most colossal failure and disappointment». 
dramatically - cannot be blamed so much on its institutional design as a more profound failure of political will of those states that were tasked with making the institution work ${ }^{2}$.

In this short contribution, then, I want to sketch out the importance of the League to the development of a modern law of international organisations (or international institutional law) — whether we consider this as a (sub-) discipline in itself or just a separate field of international legal study $-{ }^{3}$ both in a practical and symbolic sense. I will do so, first, by considering the significance of the League in terms of institutional design and function, that is, the way in which core structures and practices would foreshadow central tenets of international institutional law. Secondly, however, I wish to consider the impact of the League, and with it the scholarly efforts to come to terms with the institution, as having a more symbolic but nonetheless still central impact on contemporary concerns surrounding international institutions. In short, I will suggest that the differing images of what the League actually was in a legal sense are illustrative of continuing uncertainties and tensions at the heart of the modern discipline today.

\section{THE LEAGUE OF NATIONS AND THE EMERGENCE OF INTERNATIONAL ADMINISTRATION}

In historical narratives on the development of international law the «move to institutions» that occurred in the wake of the First World War, with the creation of the League and International Labour Organisation (ILO) together [and the Permanent Court of International Justice (PCIJ) shortly thereafter] has tended to be portrayed as a new venture for the discipline, if not for the world at large: the beginnings of a great experiment of fundamentally restructuring the international legal system ${ }^{4}$. For instance, in his by-nowclassic treatment of the topic, Inis Claude Jr. sees the «long» nineteenth century ${ }^{5}$ leading to the outbreak of the First World War, with its experiments in international administration - the various bureaux, public international unions, river commissions, and so on- as the «era of preparation for international organization», whilst the creation of the League and ILO at the start of the interbellum period represent the «era of establishment of inter-

2 SANDS, P. and KLEIN, P., Bowett's Law of International Institutions, $6^{\text {th }}$ edn, London, Thomson Reuters, 2009, p. I-021.

3 For discussion of the nature of, and some of the tensions within, "the discipline», see KLABBERS, J., «The Paradox of International Institutional Law», International Organizations Law Review, vol. 5 (2008), p. 151. For the purposes of this contribution I will use the terms international institutional law and the law of international organisations synonymously.

4 See, most famously, Kennedy, D., «The Move to Institutions», Cardozo Law Review, vol. 8 (1987), p. 841 .

5 The term was coined by the Marxist historian Eric Hobsbawm, but here I borrow it from Martti Koskenniemi: see Koskenniemi, M., "The Legacy of the Nineteenth Century», in Armstrong, D. (ed.), The Routledge Handbook of International Law, New York/Abingdon, Routledge, 2009, pp. 141 at 141-143. 
national organization ${ }^{6}$. In this somewhat teleological view of the development of modern international organisations the legacy of the League is said to lie in having consolidated earlier trends of the nineteenth century into a more recognisably modern institutional form: the administrative unions and bureaux are an obvious influence in shaping the League Secretariat; the moves towards permanent conference diplomacy, starting in Vienna in 1815 and culminating in the turn-of-the-century Hague Conferences, give rise to the League's Assembly; whilst the Concert of Europe's experiment with great power alliance and hegemony are transplanted into the permanent structures of the League Council ${ }^{7}$.

From the point of view of the modern law of international organisations, then, the League is seen as largely systematising these more ad hoc diplomatic and administrative practices into a more permanent, more recognisably modern institutional form. It is this basic constitutional architecture, the building blocks of a general plenary of all member states, a streamlined «executive» organ, and a permanent secretariat, which was to go on to be replicated in so many institutions since, though particularly in the United Nations (UN) and the many institutions that together make up the «UN system». Indeed, whilst the delegates at San Francisco tended to avoid overt references to the League in their deliberations leading to the drafting of the UN Charter, the influence of the League - in both a positive and a negative sense- was extensive enough to conclude that the new institution was in many senses simply a revised and rebooted version of a project begun some decades before ${ }^{8}$.

In this way, whilst the League clearly consolidated earlier trends, in terms of ambition and institutional design the creation of the institution in the aftermath of the Great War clearly marks out a sense of break and departure that makes it very much a product of the modern era of international organisation. This legacy comes not just from combining these organs in a by-now-quite-familiar institutional form, but also from the ambition towards the permanence of this institutional form, and indeed how such permanency left space for the constitutional development of the League into the future - even if this future turned out to be somewhat short-lived. This observation is particularly evident in relation to the League's Assembly, both in terms of its broad mandate and it having to forge a new path in carving out its own practices and procedures. Thus, on one level, in his famous history of the League, Francis P. Walters is clearly correct to observe that «never before had a full-scale international conference convened to discuss, not a specific problem or group of problems, but the whole field of international

\footnotetext{
6 See Claude JR., I., Swords into Plowshares: The Problems and Progress of International Organization, 4th edn, New York, Random House, 1971, p. 41. He also speaks of the nineteenth century institutions in terms of «ancestry», and the League-era in terms of "parentage».

7 Ibid., p. 43, and see Brölmann, C., The Institutional Veil in Public International Law: International Organizations and the Law of Treaties, Oxford, Hart Publishing, 2007.

8 CLAUdE JR., above note 6, pp. 72-74.
} 
affairs» ${ }^{9}$. Going further still, however, what really marks out the novelty of the League Assembly was the way in which it was able to autonomously determine its own practices and evolve to meet new needs. As such, despite a formal requirement for unanimity in Assembly voting, a more informal practice of majority decision-making developed at the same time as the Assembly sought to expand its functions towards a broader remit in particular in light of the Council's waning influence. In fact, as Philippe Sands and Pierre Klein note, the shifting balance of power away from the Council towards the Assembly witnessed in the early years of the League's existence has very clear parallels with the shift of power that was to later occur in the formative years of the $\mathrm{UN}^{10}$.

It was, however, in the realms of the Secretariat of the League where the largest influence on the development of a genuinely international institutional law can be traced. The importance of the League Secretariat in this sense is carving out a genuine sense of an autonomous, truly international (and in that sense recognisably modern) form of administration - what would later come to be known as the «international civil service». According to Article 1 of the League's Staff Regulations, the League's officials were to be «exclusive international officials and their duties [were] not national but international» ${ }^{11}$. Still, much of the credit for carving out a genuinely autonomous space within which international civil servants could function lies with the League's first Secretary General, sir Eric Drummond. As Christian Tams reports, Eric Drummond insisted on the recruitment of suitably high-ranking and appropriately qualified personnel, securing a degree of geographical representation from across the member states, but also avoiding the usual state-based appointments and thereby making room for a genuine spirit of internationalism to emerge ${ }^{12}$. The League's Secretariat should therefore not be seen in quite the same terms as the kind of secretarial role witnessed in the previous century's bureaux and administrative unions. In particular, high ranking League officials held privileges and immunities for the first time on a par with state diplomats ${ }^{13}$. Furthermore, League personnel were given recourse to what was then the League of Nations Administrative Tribunal, an institution which outlasted the League itself and still subsists in the (retitled) form of the ILO Administrative Tribunal, serving approximately 58,000 international civil servants across a number of institutions which recognise its jurisdiction ${ }^{14}$. Of course, with elevated power and influence would inevitably come a degree of politicization in practice, both in terms of selection of personnel and the functioning of the Secre-

9 Walters, F. P., A History of the League of Nations, Oxford, Oxford University Press, 1952, p. 128.

10 SANDS and KLEIN, above note 2, p. I-019.

11 Article 1 of the League of Nations Staff Regulations.

12 TAms, C. J., "League of Nations», in Wolfrum, R. (ed), Max Planck Encyclopedia of Public International Law, Oxford, Oxford University Press, 2008, online at: https://opil.ouplaw.com/view/10.1093/ law:epil/978 0199231690/law-9780199231690-e519.

13 Art. 7(4) League Covenant.

14 See https://www.ilo.org/tribunal/lang--en/index.htm (last accessed 12 May 2019). 
tariat ${ }^{15}$. Nevertheless, it is clear that the ideal and principle of a genuinely international administration was borne of this time.

As such, it is easy to see how this early practice and precedent would, with time and consolidation, offer a blueprint for other institutions to follow, and with it the source of a genuine sense of a law of international organisations. However, it remains clear that it is difficult to speak of a discipline or sub-discipline of study emerging as such until well into the latter half of the twentieth century. Indeed, aside from the League and ILO, interbellum institutions were still too few, and too divergent to speak confidently even of a recognisable concept of international organisation. Insofar as constitutional problems of international organisation emerged at this time such questions tended to be considered solely within the context of the particular regime itself, or else resolvable within the general law of treaties pertaining in the broader international legal system. In fact, in his brief historical survey of the field of international institutional law, Jan Klabbers claims that «[t]the interbellum period was basically a period of search, of trying to come to terms, however hesitantly, with international organizations and their place in the grander scheme of things ${ }^{16}$.

This observation is borne out in the few instances where the Permanent Court of International Justice (PCIJ) was required to consider problems related to the work and functions of the interbellum institutions. The treaty framing was particularly evident in cases directly or indirectly addressing questions of the League's institutional competence, such as Eastern Carelia $(1923)^{17}$, or Nationality Decrees $(1923)^{18}$. Nevertheless, by the late 1920s, when the Court was faced with more fundamental questions surrounding the limits of the competence of more specialized, but therefore relatively centralised institutions, it is clear that it ascribed a much greater weight of authority to the idea of international organisations as autonomous actors, thereby capable of a certain constitutional progression. Indeed, not only do we see early recognition of the problem of the development of powers and competences not explicitly set out in institutional charters in the European Commission of the Danube advisory opinion (1927) ${ }^{19}$, but also a nod towards the idea of institutions as being fundamentally imbued with the power to determine their own competence - the compétence de la compétence- in the Competence of the ILO (1926) opinion. As the Court reasoned:

«The Court does not intend to indicate the limits of any discretionary powers which the International Labour Organization may possess as regards the ma-

15 See Armstrong, D., Lloyd, L. and Redmond, J., From Versailles to Maastricht: International Organisation in the Twentieth Century, London, Palgrave, 1996, pp. 59-60.

${ }^{16}$ Klabbers, J., "The Life and Times of the Law of International Organizations», Nordic Journal of International Law, vol. 70 (2001), pp. 287 at 290.

17 Status of Eastern Carelia, Advisory Opinion, PCIJ Series B No. 5 (1923).

18 Nationality Decrees Issued in Tunis and Morocco, Advisory Opinion, PCIJ Series B No. 4 (1923).

19 European Commission of Danube Between Galatz and Braila, Advisory Opinion, PCIJ Series B No. 14 (1927). 
king of incidental regulations. The Court would exceed its own competency should it essay to consider controversial cases, actual or hypothetical, on which its opinion is not asked, and to intimate what, in its judgment, the decision upon them should be» ${ }^{20}$.

Nevertheless, what is most revealing in these cases was a hesitant search for and attempt to come to terms with the juridical nature of international institutions. This, as I now go on to show, was a concern amplified in the academic literature of this time, and it is one which arguably establishes a more indirect, symbolic, but no less important legacy for the League to the modern study of international institutional law.

\section{COMING TO TERMS WITH THE LEAGUE QUA INTERNATIONAL ORGANISATION}

That the interbellum years were in a sense an antecedent period to the development of a law of international organisations proper is perhaps best surmised by the sheer dearth of general studies on international organisations as a general phenomenon. If anything, then, it was common to highlight the unique characteristics of each institution, but particularly the League, which was most often treated as an entity almost entirely sui generis. As Catherine Brölmann notes,

«it appears that "organisations" were not considered as one formal category in the same way as they are now. Rather than concentrating on the formal characteristics of an institution as a determining factor, observers took a material and a casuistic approach. The League was perceived as an entirely new phenomenon ${ }^{21}$.

Whilst continental European jurists tended more towards systematization and generalization, it was more likely to see the trope of the "international organ» used to describe what the League was in a general sense, though the implications of this badge varied between those who saw it embodying simply a collective identity of the states that created it (e.g. in the work of Dionisio Anzilotti) and those who saw such organs as representing an interest of the international community as a whole (e. g. Pierre Kazansky ${ }^{22}$. For others, particularly Anglo-American jurists, it was the unique character of the League that was central to its identity. Indeed, insofar as many recognized that the League likely possessed an international legal personality of its own, it was the special nature of its tasks and functions that seemed to justify this conclu$\operatorname{sion}^{23}$. Thus, for Percy Corbett, the unprecedented character of the League meant that it had to be studied apart from the institutions that preceded it,

\footnotetext{
${ }^{20}$ Competence of the international labour organization to regulate, incidentally, the personal work of the employer, Advisory Opinion, PCIJ Series B No. 13 (1926) at 24.

21 BRÖLMANN, above note 7, p. 61.

22 Ibid., p. 55.

23 See e. g. Williams, J. F., «The Status of the League of Nations in International Law», reprinted in his Chapters on Current International Law and the League of Nations, New York, Longmans, Green
} 
but it was also this character which gave rise to its institutional independence and thus identity as an international person:

«The League of Nations, as the subject of rights and duties distinct from those of its Members and recognized by the vast majority of civilized countries, is a person of international law [...]

The sphere assigned to it in the conduct of international affairs is too wide to permit of relegating it [...] to the class of Zweckverbände exemplified by the Universal Postal Union, the Telegraph Union, and the international Institute of Agriculture» ${ }^{24}$.

However, whilst this unique nature seemed to pull in one direction in the sense of the organisation's independence as a legal person, the same reasoning also seemed to justify the character of the League as a kind of federation of states - functioning less as a distinct actor within international law, and more as an overarching constitution for the international system as a whole. Thus, whilst in one breath Lassa Oppenheim used the sui generis argument to justify the League's international legal personality, placing the League on the same conceptual plane as states, at least in one sense, he also uses this argument to elevate the League above them. As he puts this:

«[T] he League [of Nations] appears to be a league absolutely sui generis, a union of a kind which has never before been in existence; and its constitutional organs as well as its functions are likewise of an unprecedented kind. The Covenant of the League is an attempt to organise the hitherto unorganised community of states by a written constitution» ${ }^{25}$.

Others followed suit, either in seeing the League as a constitutional development specifically, or as an attempt at a confederation or alliance of states. Here, the image of the League is one not of separate "actorness», but as contributing to a more long-standing project of «perpetual peace», or of delivery of a promised international rule of $\operatorname{law}^{26}$. Thus, on one level -in terms of legal form - the League Covenant was a treaty giving rise to a pact between states, but on another quite profound level - that is, in terms of function or effect- the Covenant was capable of creating a separate legal identity and imbuing that entity with the capacity to fundamentally restructure the very same legal system from which it was created. Interbellum jurists such as Arnold McNair ${ }^{27}$, or Hersch Lauterpact ${ }^{28}$ were explicit on this disjunction

and Co., 1929, pp. 477-500. See also Zimmern, A., The League of Nations and the Rule of Law, 1918-1935, London/New York, MacMillan and Co, 1936, p. 467.

${ }_{24}$ CoRbett, P., "What is the League of Nations?», British Yearbook of International Law, vol. 5 (1924), p. 119 at 147. See also Oppenheim, L., "Le Caractère Essentiel de la Société des Nations», Revue Générale de Droit International Public, vol. 26 (1919), pp. 234 at 238.

25 Oppenheim, L., International Law: A Treatise, vol. 1, 3rd edn, London/New York, Longmans, Green \& Co, 1920, p. 269.

26 Most obviously, see Zimmern, above note 23; but see also Pollock, F., The League of Nations and the Coming Rule of Law, Oxford, Oxford University Press, 1918.

27 McNAIR, A., "The Functions and Differing Legal Character of Treaties», British Yearbook of International Law, vol. 11 (1930), p. 100.

28 Lauterpacht, H., "The Covenant as the Higher Law», British Yearbook of International Law, vol. 17 (1936), pp. 54 at 64-65 in particular. 
between legal form and treaty function ${ }^{29}$. For these jurists, the kind of multilateral «law-making» treaties that gave rise to international institutions could not meaningfully be considered alongside the kind of «treaty-contracts» that were more emblematic of traditional inter-state relations. As James Brierly put the same point, "[i]t is right that we should look behind the form of these treaties to their substantial effect» ${ }^{30}$.

The influence of this way of thinking to the development of a modern law of international organisations is critical. After all, many years later the International Court of Justice (ICJ) would deploy very similar language to explain the special nature of constituent instruments of international organisations:

«From a formal standpoint, the constituent instruments of international organizations are multilateral treaties, to which the well-established rules of treaty interpretation apply [...]. But the constituent instruments of international organizations are also treaties of a particular type; their object is to create new subjects of law endowed with a certain autonomy, to which the parties entrust the task of realizing common goals» ${ }^{31}$.

Nevertheless, this disjuncture is itself symptomatic of what would become ongoing tensions in the juridical character of international organisations more broadly. In fact, I believe that the interbellum debates about the juridical nature of the League foreshadow two related tensions at the core of the modern law of international organisations. The first goes to the character of international institutions in general. As a number of commentators have acknowledged, there is a noticeable schizophrenia at the core of the legal identity of international organisations. Their "open» architecture, functions as a method by which states and other actors can shape and influence the functioning of the international legal system as a whole yet, to the extent that such institutions take on a degree of autonomy to more effectively fulfil their mandate, they do so by assuming an international legal personality that «closes» them off as distinct actors existing on the same conceptual plane as states ${ }^{32}$.

Relatedly, a second tension arises in particular for institutions of universal scope such as the League or UN. Insofar as states not only work through these institutions to participate in the international legal system, but through this work also aim to fundamentally transform that system, such institutions take on the additional characteristic of being quasi-constitutional in character. Whether or not the constitutional analogy is used directly and explicitly to make sense of the UN today, as it sometimes is ${ }^{33}$, there is a difficulty in think-

\footnotetext{
${ }^{29}$ For discussion, see BrölmanN, C., «Law-Making Treaties: Form and Function in International Law», Nordic Journal of International Law, vol. 74 (2005), p. 383, as well as Chapter 7 of CoLLINS, R., The Institutional Problem in Modern International Law, Oxford/Portland, Hart Publishing, 2016.

30 BRIERLY, J. L., The Law of Nations: An Introduction to the International Law of Peace, 2nd edn, Oxford, Oxford University Press, 1936, pp. 48-49.

${ }^{31}$ Legality of the Use by a State of Nuclear Weapons in Armed Conflict, Advisory Opinion, ICJ Reports 1996,66 at $74-75$, para. 19.

32 See generally BröLMANN, above note 7; Collins, above note 29.

33 See . g. FASSBEnder, B., The United Nations Charter as the Constitution of the International Community, Leiden, Martinus Nijhoff, 2009.
} 
ing of the $\mathrm{UN}$ or the League in precisely the same manner as organisations as diverse as, for instance, NATO or the ILO. The point is not just about whether one institution is more autonomous than another, but goes to the general sense in which organisations such as the UN fulfil quite a distinct and significant role in fundamentally restructuring interstate relations. Space precludes any more detailed elaboration of this point except to say that when, in what is arguably the most landmark case in the development of the law of international organisations, the Reparation for Injuries Advisory Opinion, the ICJ recognised the international legal personality of the UN, it did so in a way by acknowledging all of the above characteristics and, in language very similar to that deployed by Percy Corbett many years before, famously claimed that «fifty States, representing the vast majority of the members of the international community, had the power, in conformity with international law, to bring into being an entity possessing objective international personality» ${ }^{34}$. And with this conclusion there ensued a whole new round of conceptual debate and contestation in coming to terms with international institutions today, in our increasingly complicated world of global governance.

Keywords: League of Nations, International Institutions, Legal Personality, Autonomy, Administration.

${ }^{34}$ Reparation for Injuries Suffered in the Service of the United Nations, Advisory Opinion, ICJ Reports 1949,174 at 185 . 